\title{
THE NURSE'S COMPETENCIES IN RELATION TO THE MOBILE EMERGENCY CARE SERVICE - SAMU
}

\section{INTEGRATIVE REVIEW}

REIS, Adilson dos ${ }^{1}$

EVARISTO, Leidiane da Silva ${ }^{2}$

SOUSA, Clarisse Cristina Ferreira Silva ${ }^{3}$

CASTRO, Mônica França de ${ }^{4}$

GUASTALDI, Rosimeire ${ }^{5}$

REIS, Adilson dos. Et al. The nurse's competencies in relation to the mobile emergency care service - SAMU. Revista Científica Multidisciplinar Núcleo do Conhecimento. 04 year, Ed. 11, Vol. 04, pp. 159-170. November 2019. ISSN: 24480959, Access link in: https://www.nucleodoconhecimento.com.br/health/nursecompetencies

\section{SUMMARY}

Introduction: In Brazil, emergency and emergency care networks are supported and regulated by the unified health system, the nursing professional is essential for the practices of care performed by mobile emergency care services (SAMU), not only with regard to guidance and medical support, it is noted that nursing has a large number of

\footnotetext{
${ }^{1}$ Graduating in Nursing.

${ }^{2}$ Graduated in Nursing.

${ }^{3}$ Graduated in Nursing.

${ }^{4}$ Graduated in Nursing.

${ }^{5}$ Doctorate in progress in Health Sciences. Master's degree in Health Sciences. Specialization in Nursing Services Management. Undergraduate nursing.
} 
functions related to its care in SAMU. Objectives: To identify nurses' work in relation to the Mobile Emergency Care Service. Method: A systematic literature review was conducted, with analysis of the main nursing journals in the Scientific Electronic Library Online databases (SciELO), Latin American and Caribbean Literature in Health Sciences (Lilacs) and the Online System for Search and Analysis of Medical Literature (Pubmed/MEDLINE). A total of 47 articles were collected with the theme of the study. Results: It was evidenced that there are a considerable amount of articles related to the nurse's competencies vis-at SAMU, and the relevance of the profession for the proper functioning of SAMU. Conclusion: It is concluded that through the scientific and technical development of the profession, with the realization of undergraduate and graduate courses, nursing attributions in relation to SAMU are considered important, but that further research is still needed by students of this category.

Keywords: Nursing, Mobile Emergency Care Service, nursing assignments.

\section{INTRODUCTION}

In Brazil, emergency and emergency care networks are supported and regulated by the unified health system, ordinance $n 1,600,2011$. And they are established by the segments of: health promotion, prevention and surveillance, in addition to mobile emergency care services (SAMU). Nurses are the professional with scientific training and human competence to deal with life, and their role is of paramount importance for care that requires invasive procedures in cases involving advanced life support units (VAS). ${ }^{1}$

Nursing is a broad science that contemplates human rights and health, with a humanized look with regard to human development and increasingly conquers its space in the most diverse health sectors. In the past, the nursing professional was seen as an auxiliary professional of the physician, today this profession with amplitude is understood, which has several contributions that favor patients, whether about information, procedure, handling of equipment and humanization. ${ }^{2}$ 
The nursing professional is essential for the practices of care performed by SAMU, not only with regard to guidance and medical support, but also in humanized care, with a wide vision of organization, team management, met equipment and maneuvers that save lives. Therefore, it is possible that nurses constantly focus on continuing education, so that it becomes increasingly specialized in the provision of First Aid, to develop their work with quality and effectiveness. ${ }^{3}$

According to Costa 2016, the nurse's performance in mobile pre-hospital care should be expanded, because it is an extremely important field for life and the more efficient this care is, the greater the chance of an individual's life. Accordingly, for Mendes 2010, the Mobile Emergency Care Service - SAMU represents a crucial care for the individual who goes through some health complications, and needs to be attended by professionals fit and able to perform all necessary procedures, aiming at the preservation of life ${ }^{3}$

The quality of health services offered in Brazil in the 1980s underwent significant changes, driven by the lack of financial resources evidencing the importance of adopting a new way of managing and managing financial resources. The quality management done by nursing represents great importance, therefore it is understood as a strategy that achieves an acceptable continuous standard of quality care. Management enables the development of human resources generating responsibilities to the team, including managers and administrators. ${ }^{4}$

Recognizing that nurses are indispensable in pre-hospital care, it becomes of great interest to understand the competencies and contributions to the area, the question arises: what are the nurse's attributions in relation to care in the Samu?

\section{THEORETICAL FRAMEWORK}

The high demand for effective emergency care services and medical emergencies has generated several models of care systems around the world. In Brazil, the first proposal took place in 2003, through the National Policy of Attention to Emergencies - (PNAU) ${ }^{5}$ 
According to Mendes 2010, this policy represents the effort of the Ministry of Health to organize regional flows of comprehensive care for cases of urgency and emergency in Brazil. Thus, the PNAU is guided by the principles of the SUS and is structured in five axes, these: promoting quality of life; networking; operation of regulatory plants; training and continuing education; humanization of attention. ${ }^{6}$

Its implementation was marked by the mobile pre-hospital component, presenting itself as a strategy in the Mobile Emergency Care Service (SAMU), constituting a standardized model of care, in which care is provided after a call free of charge for the number 192, and the medical center defines how care should be conducted. ${ }^{6}$

In addition, there was an expansion of access to services, not only through the service provided by SAMU, as well as the implementation of the Emergency Care Units (UPA), which present themselves as the most recent strategy of the policy, uniting the strategy of training and continuing education of professionals, called Nuclei and Education and Urgency. ${ }^{6}$

\section{RESULTS}

Seeking to understand the importance of nurses in relation to the mobile emergency service (SAMU), during data collection, taking into account the inclusion and exclusion criteria, 9 scientific articles were found that addressed the competencies nurses' care and managerial sects in publications presented in the tables in the previous item, in two stages, the first says about the characterization of published articles regarding the title, place, author, year, type of study and objective and the second regarding the related skills and activities and percentage.

The data collection of this integrative review resulted through the selection of the studies described in Table 1 
Table 1 - Characterization of published articles regarding title, place, author, year, type of study and objective. São Paulo, 2019

\begin{tabular}{|c|c|c|c|c|}
\hline Identification & Title, author & $\begin{array}{l}\text { Location, } \\
\text { year }\end{array}$ & $\begin{array}{l}\text { Type of } \\
\text { study }\end{array}$ & Goal \\
\hline A1 & $\begin{array}{l}\text { Nurses of the } \\
\text { emergency mobile } \\
\text { care service: } \\
\text { profile and } \\
\text { activities } \\
\text { developed. } \\
\text { Luchtemberg MN, } \\
\text { Pires DEP }\end{array}$ & $\begin{array}{l}\text { Florianópolis, } \\
2015\end{array}$ & $\begin{array}{l}\text { Qualitative } \\
\text { descriptive } \\
\text { study }\end{array}$ & $\begin{array}{l}\text { Characterize the } \\
\text { profile and } \\
\text { identify the } \\
\text { activities } \\
\text { developed by } \\
\text { nurses from the } \\
\text { emergency } \\
\text { mobile care } \\
\text { service of a state } \\
\text { in southern } \\
\text { Brazil }\end{array}$ \\
\hline A2 & $\begin{array}{l}\text { Continuing } \\
\text { continuing } \\
\text { continuing } \\
\text { education as } \\
\text { management } \\
\text { strategies in the } \\
\text { emergency mobile } \\
\text { care service. Hetti } \\
\text { LBE, Bernardes A, } \\
\text { Gabriel CS, } \\
\text { Fortuna CM, } \\
\text { Maziero VG. }\end{array}$ & $\begin{array}{l}\text { São Paulo, } \\
2013\end{array}$ & $\begin{array}{l}\text { Qualitative } \\
\text { study }\end{array}$ & $\begin{array}{l}\text { The study aimed } \\
\text { to analyze the } \\
\text { perception of } \\
\text { professionals } \\
\text { about } \\
\text { permanent } \\
\text { and/or continued } \\
\text { education in the } \\
\text { Mobile } \\
\text { Emergency Care } \\
\text { Service of a } \\
\text { municipality in } \\
\text { the State of São } \\
\text { Paulo }\end{array}$ \\
\hline A3 & $\begin{array}{l}\text { The } \\
\text { nurse/manager's }\end{array}$ & $\begin{array}{l}\text { Tocantins, } \\
2014 .\end{array}$ & $\begin{array}{l}\text { Descriptive } \\
\text { and }\end{array}$ & $\begin{array}{l}\text { Analyze the } \\
\text { nurse/ge's view }\end{array}$ \\
\hline
\end{tabular}




\begin{tabular}{|c|c|c|c|c|}
\hline & $\begin{array}{l}\text { view on the needs } \\
\text { to implement } \\
\text { psychological } \\
\text { support to } \\
\text { professionals in } \\
\text { the emergency } \\
\text { mobile care } \\
\text { service; Meskita } \\
\text { KL, Gomes GPLA, } \\
\text { Silvar MJBF, } \\
\text { Santos LF. }\end{array}$ & & $\begin{array}{l}\text { exploratory } \\
\text { qualitative } \\
\text { research }\end{array}$ & $\begin{array}{l}\text { on the need to } \\
\text { implement } \\
\text { psychological } \\
\text { support to } \\
\text { SAMU } \\
\text { professionals }\end{array}$ \\
\hline A4 & $\begin{array}{l}\text { The daily life of } \\
\text { nurses working in } \\
\text { the emergency } \\
\text { mobile care } \\
\text { service. Tavares } \\
\text { TY, Santana JCB, } \\
\text { Eloy MD, Oliveira } \\
\text { RD, Paula RF }\end{array}$ & $\begin{array}{l}\text { Minas } \\
\text { Gerais, } 2017\end{array}$ & $\begin{array}{l}\text { Qualitative } \\
\text { and } \\
\text { exploratory } \\
\text { research }\end{array}$ & $\begin{array}{l}\text { Understanding } \\
\text { the daily work of } \\
\text { nurses working } \\
\text { in the Mobile } \\
\text { Emergency Care } \\
\text { Service }\end{array}$ \\
\hline A5 & $\begin{array}{l}\text { Perspectives of } \\
\text { nurses in care in } \\
\text { mobile pre- } \\
\text { hospital care. } \\
\text { Anjos MS, Oliveira } \\
\text { SS, Rosa DOS }\end{array}$ & Bahia, 2016 & $\begin{array}{l}\text { Qualitative } \\
\text { exploratory } \\
\text { study }\end{array}$ & $\begin{array}{l}\text { Describe the } \\
\text { perspectives of } \\
\text { nurses in care in } \\
\text { mobile pre- } \\
\text { hospital care. }\end{array}$ \\
\hline A6 & $\begin{array}{l}\text { Nurses' } \\
\text { performance in } \\
\text { mobile pre- } \\
\text { hospital care. } \\
\begin{array}{llr}\text { Adão } & \text { RS, } & \text { Santos } \\
\text { MR. }\end{array}\end{array}$ & $\begin{array}{l}\text { São Paulo, } \\
2013\end{array}$ & $\begin{array}{l}\text { Qualitative } \\
\text { bibliographic } \\
\text { review }\end{array}$ & $\begin{array}{l}\text { The objective } \\
\text { with this study } \\
\text { was to describe } \\
\text { the actions of } \\
\text { nurses in a basic } \\
\text { and advanced }\end{array}$ \\
\hline
\end{tabular}




\begin{tabular}{|c|c|c|c|c|}
\hline & & & & $\begin{array}{l}\text { health unit in } \\
\text { mobile PHA, } \\
\text { through literary } \\
\text { review. }\end{array}$ \\
\hline A7 & 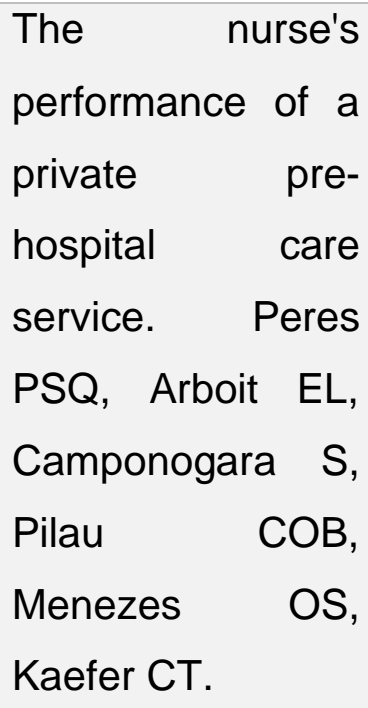 & $\begin{array}{l}\text { Rio Grande } \\
\text { do Sul, } 2018\end{array}$ & $\begin{array}{l}\text { Qualitative } \\
\text { exploratory } \\
\text { descriptive } \\
\text { study }\end{array}$ & $\begin{array}{l}\text { To know the } \\
\text { perception of } \\
\text { health workers } \\
\text { about the } \\
\text { nurse's } \\
\text { performance in a } \\
\text { pre-hospital care } \\
\text { service. }\end{array}$ \\
\hline A8 & $\begin{array}{l}\text { Nurses' } \\
\text { performance in } \\
\text { mobile pre- } \\
\text { hospital care. } \\
\text { Fernandez MG, } \\
\text { Espindula BM. }\end{array}$ & $\begin{array}{l}\text { São Paulo, } \\
2018\end{array}$ & $\begin{array}{l}\text { Integrative } \\
\text { review of the } \\
\text { literature }\end{array}$ & $\begin{array}{l}\text { The objective } \\
\text { with this study } \\
\text { was to describe } \\
\text { the actions of } \\
\text { nurses in a basic } \\
\text { and advanced } \\
\text { health unit in } \\
\text { mobile PHA, } \\
\text { through literary } \\
\text { review. }\end{array}$ \\
\hline A9 & $\begin{array}{l}\text { Supervision of } \\
\text { nurses in mobile } \\
\text { pre-hospital care. } \\
\text { Bernardes A, } \\
\text { Maziero GV, Hetti } \\
\text { LBE, Baldin MSC, } \\
\text { Gabriel CS. }\end{array}$ & $\begin{array}{l}\text { São Paulo, } \\
2014\end{array}$ & $\begin{array}{l}\text { Qualitative } \\
\text { descriptive } \\
\text { research }\end{array}$ & $\begin{array}{l}\text { The study aimed } \\
\text { to analyze how } \\
\text { supervision } \\
\text { occurs in the } \\
\text { Mobile } \\
\text { Emergency Care } \\
\text { Service (SAMU) }\end{array}$ \\
\hline
\end{tabular}


Source: Kings, 2019.

The selected studies were analyzed and grouped according to competencies found, activities and percentage, described in Chart 2.

Table 2: Distribution of the articles found regarding the care and managerial competencies. São Paulo, 2019

\begin{tabular}{|c|c|c|c|}
\hline Type & Articles & Activities & $\%$ \\
\hline Assistance & $\begin{array}{l}\text { A1 } \\
\text { A4 } \\
\text { A5 } \\
\text { A6 } \\
\text { A7 } \\
\text { A8 }\end{array}$ & 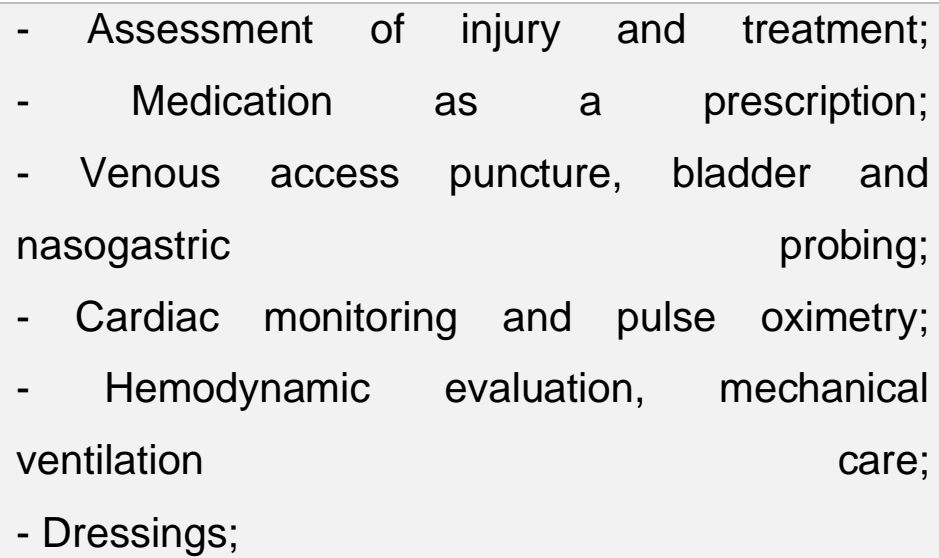 & $66,6 \%$ \\
\hline Management & $\begin{array}{l}\text { A2 } \\
\text { A3 } \\
\text { A9 }\end{array}$ & 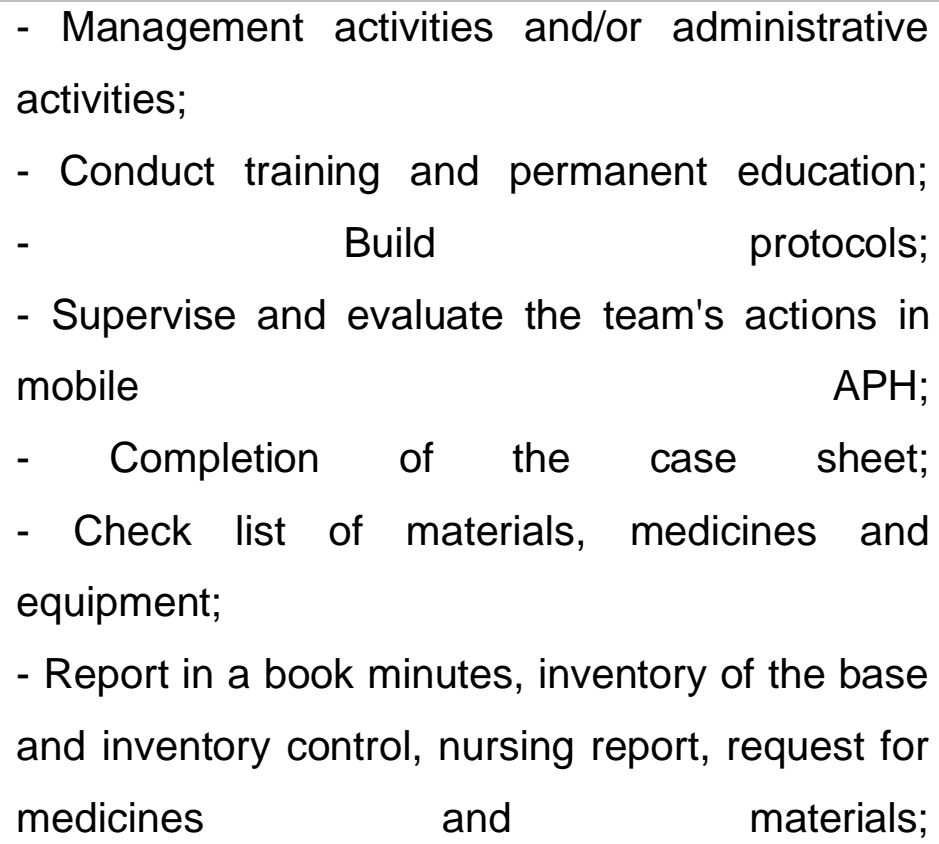 & $33,3 \%$ \\
\hline
\end{tabular}




\begin{tabular}{|c|c|}
\hline & $\begin{array}{l}\text { - Disinfection of equipment and vehicle; } \\
\text { - Controlled drug form, transfer responsibility term, } \\
\text { warehouse temperature control; } \\
\text { - Scale of disinfection of the vehicle, filling medical } \\
\text { records, participation in the elaboration of projects } \\
\text { such as the samu educates; } \\
\text { - Participation of meetings and filling of the point } \\
\text { sheet }\end{array}$ \\
\hline Total: & \\
\hline
\end{tabular}

Source: Kings, 2019

\section{DISCUSSION}

To better understand the results, they will be discussed in two topics: care skills for the nurse's performance in SAMU and management skills for the nurse's role in SAMU.

\section{CARE SKILLS OF NURSES TO ACT IN SAMU}

The publications addressed the nurse's competencies, both care and management simultaneously, but $33 \%(n=3)$ of the publications, the main focus was the nurse's performance as a manager, among the care skills found, the ones that stand out the most and are recurrent are: evaluation of the extent of the diseases giving priority to greater commitment and performance of procedures and care. Standing out among the procedures, venous puncture, passage of bladder cutting tube and nasogastric probing, while in the provision of care was found: performance of dressings, monitoring of vital signs and administration of medications, cardiac monitoring and pulse oximetry, hygiene and comfort, hemodynamic evaluation, immobilizations, anamnesis, physician assistance in procedures such as resuscitation and decision-making. ${ }^{6}$

Among others. Given the multiple functions performed by the nurse, it is clear the idea of the importance of the nurse and the responsibility given to him, which requires the development of skills that involve cognition, attitudes and the performance of the 
procedures, which ends by result in the role of manager, meaning in many cases the emergence of physical and mental exhaustion. Therefore, it is essential to provide human and physical resources in order to provide the best care to the victim, always aiming at minimizing the problems.

\section{MANAGERIAL SKILLS OF NURSES TO WORK IN SAMU}

For the main management competencies, it was evidenced that, it is the role of nurses to develop protocols for the correct provision of care, considering all the sample that justifies the patient's care and commitment.8 Also, with the patient's nurse, the completion of the attendance form, checking and replenishment of the stock of materials that must be in the vehicle and that are relevant to care, disinfection of equipment and vehicle, nursing report, participation or development of projects that enable health education permanently. ${ }^{9}$

Given the evidence of nurses' competencies, it is understood the importance and that this professional is indispensable considering both the care and managerial activities, which are deprived of the nurse, as well as to provide support to the collaborators of the nursing team, which leads to the quality index of care delivery, understanding that non-performance, non-knowledge of their relevant activities can characterize damage or death to the victim attended. ${ }^{9}$

Aiming beyond everything, the good quality of nursing care is custoly up to the nurse to manage the nursing team, and the same should be responsible for the size of the team, considering the performance of each employee, the elaboration protocols that based on scientific evidence and adapted to the reality of Brazilian health, provide ways to perform care and that supports the actions of the professional.10 According to Santos and Adam, 2013 the introduction of the professional Nurse in care mobile pre-hospital was given through the PNAU, which comes into agreement with what the Regional Nursing Council says, which considers this professional important for the composition of the PHA team, since it is able to develop actions with the aim of preserve and reduce damage to life, either through direct assistance or team management. ${ }^{10}$ 
As a manager, one of the most important responsibilities of nurses is continuing health education, since it has theoretical and scientific knowledge. This health education is more routinely translated by the guidance and explanations passed on to the victim's family than properly to nursing employees, where nurses are responsible for the training and training of their employees, aiming at better quality of the services provided..$^{1,10}$

\section{CONCLUSION}

Of the 9 articles identified to achieve the proposed objectives, $100 \%(n=9)$ addressed care skills, but of this total, only $33 \%(n=3)$ addressed the management competencies of the nursing category. For management competencies, the ones that stood out were those that have a direct relationship with the victim, such as the provision of care. While managers found skills that are not directly linked to the victim, with administrative activities as the main ones, such as team sizing. It is concluded that nurses are an indispensable professional both in direct care to the victim and in the actions that coordinate this care.

\section{REFERENCES}

1. LUCHTEMBERG, Marilene Nonnemacher; PIRES, Denise Elvira Pires de. Enfermeros del Servicio de Atención Móvil de Urgencia: profile y desarrolladas activities. Brazilian Journal of Nursing, v. 69, n. 2, p. 213-220, 2016.

2. Adam, Rodrigo de Souza; SANTOS, Maria Regina dos. Nurses' performance in mobile pre-hospital care. Revista Mineira de Enfermagem, v. 16, n. 4, p. 601-608, 2012.

3. BERNARDES, Andrea et al. Supervision of nurses in mobile pre-hospital care. Electronic Nursing Journal, v. 16, n. 3, p. 635-43, 2014.

4. BRAZIL, Ministry of Health. National Policy for Emergency Care. Brasília, Editor of the Ministry of Health, 3. ed. ampl., 2006. 
5. COSTA, Gabriela. An approach to nursing history action in the face of health policies. Revista Mineira de Enfermagem - REME; vol 10.4; João Pessoa - PB, 2016

6. EL HETTI, Livia Barrionuevo et al. Continuing/continuing education as management strategies in the Mobile Emergency Care Service. Electronic Nursing Journal, v. 15, n. 4, p. 973-82, 2013.

7. MENDES, Eugênio Vilaça. Health care networks. Ciênc. collective health, Rio de Janeiro, v. 15, n. 5, p. 2297-2305, Aug. 2010.

8. MESQUITA, Kayena Lopes et al. The nurse/manager's view on the need to implement psychological support to professionals in the emergency mobile care service. Nursing journal of the midwest Of Minas Gerais, 2014.

9. NETTINA, Sandra ( Nursing Practice. 9th Ed. Rio de Janeiro: Guanabara Koogan, 2011.

10. PERES, Paulo Sergio Quevedo et al. Nurses' performance in a private prehospital care service/Nurse performance on a private prehospital assistance. Research Magazine: Caution is Fundamental Online, v. 10, n. 2, p. 413-422, 2018.

11. TAVARES, Tayrine Ypuena et al. The daily life of nurses working in the emergency mobile care service. Nursing Journal of The Midwest of Minas Gerais, v. 7, 2017.

Submitted: November, 2019.

Approved: November, 2019. 